\title{
Monocarboxylate Transporter 3
}

National Cancer Institute

\section{Source}

National Cancer Institute. Monocarboxylate Transporter 3. NCI Thesaurus. Code C134627.

Monocarboxylate transporter $3(504 \mathrm{aa}, \sim 52 \mathrm{kDa}$ ) is encoded by the human SLC16A8 gene. This protein plays a role in transmembrane transport of monocarboxylates. 